\title{
ANALYSIS OF CONFORMATIONAL FLEXIBILITY OF LOOP 110-120 OF PROTEIN TYROSINE PHOSPHATASE 1B
}

\author{
V. Yu. TANCHUK, V. O. TANIN, A. I. VOVK \\ Institute of Bioorganic Chemistry and Petrochemistry, \\ National Academy of Sciences of Ukraine, Kyiv; \\ e-mail:v_tanchuk@yahoo.com; vovk@bpci.kiev.ua
}

\begin{abstract}
Conformations of the catalytic center of protein tyrosine phosphatase $1 B(P T P 1 B)$ and surrounding loops are known to be important in catalysis and inhibition of the enzyme. There were 98 conformations from 88 PDB files representing PTP1B with different ligands which were analyzed to investigate the details of loop 110-120 movement and mobility of separate residues. The differences were identified by a special software tool which performs multiple comparisons of selected parts of PDB files. The conformations were divided into 6 clusters. It was found that the loop formed by residues 110-120 can be characterized by four main conformations. Predominantly, the loop 110-120 adopts the main conformation and keeps it during WPD loop movement. Three other conformations appear to be stabilized in case of closed WPD loop and seem to be favorable for PTP1B with subunit structure.
\end{abstract}

Key words: protein tyrosine phosphatase 1B, binding sites, conformations, clustering, structure similarity, docking.

$\mathrm{M}$ ore than a hundred protein tyrosine phosphatases can function either as negative or positive modulators in various signal transduction metabolic routes in the human organism [1]. Phosphorylation and dephosphorylation of protein residues in the living cell catalyzed by protein tyrosine phosphatases is known to be a key to regulating the biochemical processes. Cellular metabolic routes controlled by tyrosine dephosphorylation offer a wide range of drug targets for developing novel therapeutics [2]. Intracellular protein tyrosine phosphatase 1B (EC 3.1.3.48) implicated in insulin receptor dephosphorylation is considered as a negative regulator of insulin signal transduction and can also dephosphorylate the leptin receptor-associated kinase [3]. Therefore PTP1B is one of the most promising therapeutic targets for potential treatment of type 2 diabetes and obesity [4]. There is growing interest in developing of potent and selective inhibitors for this enzyme [5, 6], especially derivatives of carboxylic, phosphonic, sulfonic acids, heterocyclic and other compounds, which have been identified as PTP1B inhibitors [7, 8]. A lot of active compounds have been studied by using computer-based approaches, including molecular docking. Docking results were also used to understand detailed mechanisms of inhibitor binding to the enzyme $[9,10]$.

Flexibility of proteins is an intrinsic property of biological importance being involved in catalysis, as well as substrate recognition or inhibitor binding [11]. Conformational features of WPD loop Thr177-Pro185), R-loop (Val113-Ser118) and S-loop (Val198-Gly209) of PTP1B provide a smooth entrance and favorable microenvironment for the substrates and inhibitors moving into the binding pocket [12]. It is known that at least WPD loop is a great challenge for computer modeling of enzyme-inhibitor complexes. There are more than 100 PDB files in the RSCB Protein Data Bank [13] which represent this enzyme with different inhibitors. In this case an investigator is able to analyze these conformations of binding site and find the most representative among them. As more and more data appear for different ligand-enzyme complexes, this approach becomes more and more feasible.

In our previous work [14] a special tool for the analysis of experimental conformations of the active site of PTP1B was used. The analyzed fragment included the vicinity of catalytic Cys215, WPD loop and a secondary binding site (Arg24, His25, Ala27, Phe52, Arg254, Met258 and Gly259). It was found that almost all of the most mobile residues belong to the flexible WPD-loop. Lys120 appeared to be highly mobile (RMSD deviation over 109 conformations $2.53 \AA$ ). Lys120 is positioned near the R-loop, which has been identified as an important structural feature of PTP1B from molecular dynamic study [15] and these flexible residues were also referred to as loop 110-120 [16]. WPD loop and loop 110-120 look like two large "paws" 
protecting the entrance to the catalytic pocket (Fig. 1).

High mobility of Lys120 [14] which is located at the beginning of the loop supports an idea that the loop $110-120$ is flexible and may probably play an important role in the functioning of PTP1B [15]. We have already used 32 residues in both catalytic and vicinal binding sites of PTP1B of chain A of 1Q6T [17] alongside with the residues of the WPD loop as a template to find in all other files. In this paper the fragment was extended by adding the loop 110-120 and neighboring residues 121-125 to analyze the molecular details of the loop 110-120 movement and mobility of separate residues of this loop of PTP1B.

\section{Methods}

Analysis of crystal structures of PTP1B was carried out using a special software tool created by the authors [14]. The program ACTPDBCMP (Active Part of PDB Comparison) finds a specified fragment in all PDB files, builds a distance matrix of the found fragments (RMSD of all atoms of the fragment) and later performs hierarchical cluster analysis. The centroids of the found clusters represent the most typical conformations of the fragment's residues.

A total of 113 PDB files were selected by 'PTP1B' query from the RSCB Protein Data Bank. Twenty five files have not been accepted by our software. Some of them had mutations in their active site regions, some were not in fact PTP1B (for example, 2FET), and the other lacked some residues. Ninety eight fragments (sites) were found in the 88 remaining PDB files.

Swiss PDB-Viewer [18] and Ligplot [19] were used for visualization.

\section{Results and Discussion}

Using the database from 88 PDB files, we have determined the mobility of amino acid residues of PTP1B. Root mean square deviations for all residues belonging to the examined part of the PTP1B chain are given in Table 1. The data demonstrate essential contribution of 110-120 amino acid residues to the total variability of conformations. Apart from absolute and relative average deviations, maximal and minimal values with corresponding pairs of crystal structures are presented. As shown in Table 1, the most mobile residues are Glu115, Leu119, Ser118, Lys120, Gly117 and Met114, located in the middle and on one side of this loop. In comparison with this, the flexibility of residues on the other side of the loop (Arg112, Asn111 and Val113) is significantly lower. Moderate changes are observed for Leu110 being placed at the end of the list. It should be mentioned that Leu119 is considered to be selectivity determinant between PTP1B and TC-PTP [16]. This residue can interact with bulky inhibitors and its mobility

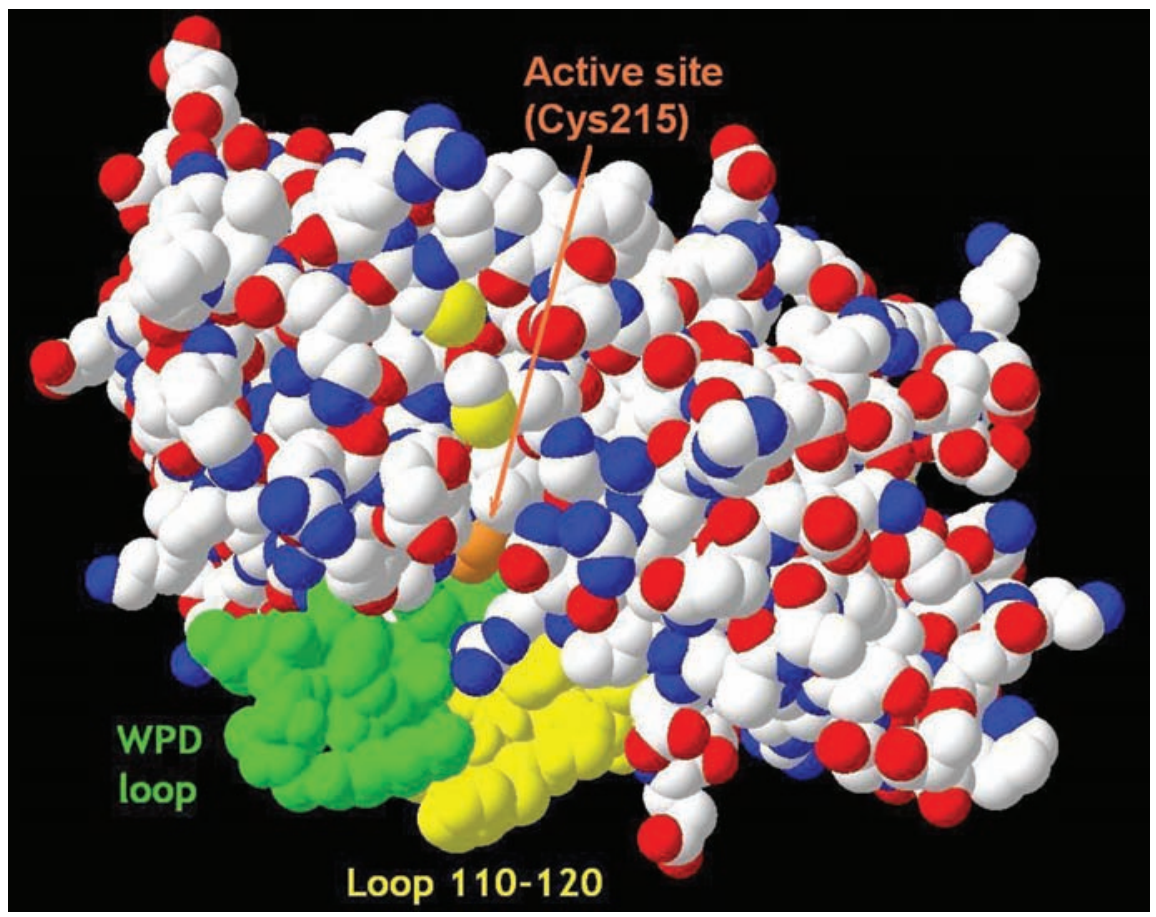

Fig. 1. WPD loop (open conformation) and loop 110-120 (standard conformation) seem to protect the entrance to the active site of PTP1B (1PHO) 
Table 1. Analyzed amino acid residues sorted by their mobility ${ }^{a}$

\begin{tabular}{|c|c|c|c|c|c|c|c|c|}
\hline \multirow{2}{*}{$\begin{array}{l}\text { Residue } \\
\text { Phe182 }\end{array}$} & \multirow{2}{*}{$\begin{array}{c}\text { Average } \\
\text { RMSD, } \\
\AA \\
4.64\end{array}$} & \multirow{2}{*}{$\begin{array}{c}\text { Average } \\
\text { RMSD } \\
\% \\
100.0\end{array}$} & \multirow{2}{*}{$\begin{array}{c}\text { Max. } \\
\text { RMSD, } \\
\AA \\
9.43\end{array}$} & \multicolumn{2}{|c|}{$\begin{array}{l}\text { Max. PDB } \\
\text { files RMSD }\end{array}$} & \multirow{2}{*}{$\begin{array}{c}\text { Min. } \\
\text { RMSD, } \\
\AA \\
0.04\end{array}$} & \multicolumn{2}{|c|}{$\begin{array}{l}\text { Min. PDB files } \\
\text { RMSD }\end{array}$} \\
\hline & & & & 1Q6T-B & 1JF7 & & 2 F71 & $2 \mathrm{~F} 6 \mathrm{~V}$ \\
\hline Lys116 & 4.00 & 86.3 & 11.73 & 1Q6N & $1 \mathrm{BZH}$ & 0.06 & 2QBS & 2QBQ \\
\hline Asp181 & 3.63 & 78.3 & 7.70 & $3 \mathrm{I} 7 \mathrm{Z}$ & $1 N N Y$ & 0.04 & 1LQF-C & 1LQF-B \\
\hline Glu115 & 3.57 & 77.1 & 11.37 & 1Q6J & $1 \mathrm{BZH}$ & 0.04 & 2F6Z & $2 \mathrm{~F} 6 \mathrm{~T}$ \\
\hline Leu119 & 3.43 & 74.1 & 9.81 & 1Q6P & 1Q6J & 0.04 & $2 \mathrm{~F} 6 \mathrm{Z}$ & $2 \mathrm{~F} 6 \mathrm{~T}$ \\
\hline Arg47 & 2.56 & 55.2 & 8.69 & 1OES & 1NL9 & 0.08 & 1Q6M & 1Q6J \\
\hline Asp48 & 2.24 & 48.4 & 7.81 & 1Q6P & 1OEM & 0.07 & $3 \mathrm{I} 80$ & 1WAX \\
\hline Ser118 & 2.17 & 46.8 & 7.67 & 2FJN-B & 1Q6T-B & 0.03 & $2 \mathrm{~F} 71$ & $2 \mathrm{~F} 6 \mathrm{~T}$ \\
\hline Lys120 & 2.08 & 44.9 & 6.36 & $2 \mathrm{FJN}$ & 1JF7 & 0.05 & 2 F70 & $2 \mathrm{~F} 6 \mathrm{~V}$ \\
\hline Gly117 & 1.94 & 41.8 & 7.71 & $2 \mathrm{FJN}$ & $1 \mathrm{Q} 6 \mathrm{~N}$ & 0.06 & $2 \mathrm{~F} 6 \mathrm{~V}$ & $2 \mathrm{~F} 6 \mathrm{~T}$ \\
\hline Met114 & 1.87 & 40.4 & 7.28 & 1Q6N & $1 \mathrm{LQF}$ & 0.04 & 2 F71 & $2 \mathrm{~F} 6 \mathrm{~T}$ \\
\hline $\operatorname{Arg} 24$ & 1.68 & 36.1 & 4.07 & 1LQF-C & 1JF7 & 0.10 & 2ZN7 & $2 \mathrm{ZMM}$ \\
\hline Tyr46 & 1.67 & 36.0 & 6.94 & 2FJN-B & 1OES & 0.04 & 2QBS & 2QBQ \\
\hline Gly218 & 1.66 & 35.8 & 7.08 & 3SME & $1 \mathrm{JF} 7$ & 0.03 & 2ZN7 & 2QBP \\
\hline Ile219 & 1.61 & 34.8 & 7.01 & 3SME & $1 \mathrm{PH} 0$ & 0.04 & $2 \mathrm{ZMM}$ & 2QBR \\
\hline Gly183 & 1.57 & 33.8 & 3.19 & 1JF7 & $1 \mathrm{C} 84$ & 0.03 & $2 \mathrm{~F} 6 \mathrm{Z}$ & $2 \mathrm{~F} 6 \mathrm{~V}$ \\
\hline Prol80 & 1.48 & 31.8 & 3.28 & $2 \mathrm{FJN}$ & 1JF7 & 0.05 & 2F6V & $2 \mathrm{~F} 6 \mathrm{~T}$ \\
\hline Prol85 & 1.40 & 30.3 & 2.93 & $2 \mathrm{CNE}$ & 1OEM & 0.04 & 1LQF-C & $1 \mathrm{LQF}$ \\
\hline $\operatorname{Arg} 112$ & 1.39 & 29.9 & 4.15 & 1Q6N & 1LQF-D & 0.07 & 2VEX & $2 \mathrm{VEV}$ \\
\hline Gln262 & 1.29 & 27.8 & 3.01 & $1 \mathrm{SUG}$ & 1OEM & 0.07 & $1 \mathrm{LQF}-\mathrm{C}$ & 1LQF-B \\
\hline Val184 & 1.20 & 25.9 & 2.61 & $2 \mathrm{CNE}$ & 1OEM & 0.04 & 2F6V & $2 \mathrm{~F} 6 \mathrm{~T}$ \\
\hline Trp179 & 1.18 & 25.4 & 2.85 & 1Q6N & $1 \mathrm{G} 7 \mathrm{~F}$ & 0.03 & 2QBS & 2QBQ \\
\hline Ala217 & 1.02 & 21.9 & 4.28 & 3SME & 1JF7 & 0.03 & $2 \mathrm{CNE}$ & 1Q6S \\
\hline Gln123 & 0.95 & 20.5 & 2.24 & 2FJN-B & 1OEM & 0.05 & $2 \mathrm{VEX}$ & $2 \mathrm{CNI}$ \\
\hline Asp29 & 0.93 & 20.2 & 2.63 & $2 \mathrm{CNE}$ & $1 \mathrm{G} 7 \mathrm{~F}$ & 0.09 & $2 \mathrm{HB} 1$ & $2 \mathrm{H} 4 \mathrm{G}$ \\
\hline $\operatorname{Arg} 254$ & 0.92 & 19.8 & 3.67 & $1 \mathrm{Q} 6 \mathrm{~N}-\mathrm{B}$ & 1OES & 0.05 & $2 F 71$ & $2 \mathrm{~F} 6 \mathrm{~T}$ \\
\hline Thr178 & 0.89 & 19.3 & 1.90 & $2 \mathrm{CNE}$ & 1NL9 & 0.03 & $2 F 71$ & $2 \mathrm{~F} 6 \mathrm{~T}$ \\
\hline Asn111 & 0.86 & 18.6 & 1.43 & 1Q6P-B & 1OEM & 0.04 & 2QBS & 2QBR \\
\hline Val113 & 0.83 & 17.9 & 2.39 & 1Q6M & 1JF7 & 0.02 & $2 \mathrm{~F} 6 \mathrm{~V}$ & $2 \mathrm{~F} 6 \mathrm{~T}$ \\
\hline Val49 & 0.82 & 17.7 & 3.11 & 1OEM & $1 \mathrm{LQF}$ & 0.06 & $2 \mathrm{~F} 70$ & 2CM8 \\
\hline Ser216 & 0.77 & 16.6 & 2.58 & 3SME & 3D9C & 0.04 & $2 \mathrm{~F} 6 \mathrm{~V}$ & $2 \mathrm{~F} 6 \mathrm{~T}$ \\
\hline $\operatorname{Arg} 221$ & 0.76 & 16.3 & 1.53 & 3D9C & $2 \mathrm{FJN}$ & 0.03 & 2 F71 & $2 \mathrm{~F} 6 \mathrm{~T}$ \\
\hline Cys121 & 0.73 & 15.6 & 2.19 & 1Q6P-B & 1OES & 0.04 & 2 F71 & $2 \mathrm{~F} 6 \mathrm{~T}$ \\
\hline Thr177 & 0.72 & 15.5 & 1.40 & 2FJN-B & $2 \mathrm{CNF}$ & 0.04 & $2 \mathrm{~F} 6 \mathrm{Z}$ & $2 \mathrm{~F} 6 \mathrm{~T}$ \\
\hline Ser28 & 0.71 & 15.3 & 1.72 & $2 \mathrm{CMB}$ & 1OES & 0.04 & $2 \mathrm{~F} 6 \mathrm{Y}$ & $2 \mathrm{~F} 6 \mathrm{~T}$ \\
\hline Gly120 & 0.68 & 14.6 & 2.38 & 3SME & 1Q6P-B & 0.02 & $2 \mathrm{~F} 6 \mathrm{~V}$ & $2 \mathrm{~F} 6 \mathrm{~T}$ \\
\hline Met258 & 0.67 & 14.4 & 1.93 & 1Q6P-B & 1OEM & 0.05 & $2 \mathrm{CNH}$ & $2 \mathrm{CMB}$ \\
\hline Ala27 & 0.66 & 14.2 & 2.01 & $2 \mathrm{CMB}$ & 1OES & 0.03 & $2 \mathrm{CM} 7$ & $1 \mathrm{BZC}$ \\
\hline Phe30 & 0.65 & 14.0 & 1.65 & 1Q6J & 1OES & 0.05 & 2ZMM & $2 \mathrm{H} 4 \mathrm{~K}$ \\
\hline
\end{tabular}




\section{Table 1. Continue}

\begin{tabular}{lcccccccc}
\hline Tyr176 & 0.63 & 13.7 & 1.36 & 1Q6M & 1OES & 0.03 & 2F6Z & 2F6T \\
Gly259 & 0.63 & 13.6 & 1.86 & 1SUG & 1OEM & 0.03 & 2F6W & 2BGD \\
Ala122 & 0.63 & 13.6 & 2.16 & 2FJN-B & 1OEM & 0.04 & 2ZN7 & 2ZMM \\
Phe52 & 0.56 & 12.1 & 1.56 & 1Q6J & 1OES & 0.05 & 2F6V & 2F6T \\
Trp125 & 0.55 & 11.8 & 1.74 & 2FJN-B & 1OEM & 0.04 & 2ZN7 & 2B07 \\
Cys215 & 0.51 & 10.9 & 1.51 & 3D9C & $1 \mathrm{Q} 6 \mathrm{~N}$ & 0.02 & 2F6V & 2F6T \\
Tyr124 & 0.50 & 10.7 & 1.64 & 2FJN-B & 1OEM & 0.03 & 2F71 & 2F6T \\
Ser222 & 0.48 & 10.4 & 1.05 & 2CNH & 1OES & 0.03 & 2VEV & 2QBP \\
Leu110 & 0.44 & 9.5 & 1.17 & 2VEU & 1OEM & 0.03 & 2F6V & 2F6T \\
\hline
\end{tabular}

${ }^{a}$ Average RMSD for all conformations as well as maximum and minimum RMSD and corresponding pairs of PDB entries are presented. The designations $-\mathrm{B},-\mathrm{C},-\mathrm{D}$ mean chains $\mathrm{B}, \mathrm{C}, \mathrm{D}$ in corresponding PDB files.

may be an important factor in selectivity of the inhibition.

Analysis of 98 monomeric forms of PTP1B with the help of ACTPDBCMP resulted in the finding of 6 groups (clusters) of similar conformations. The results are summarized in Table 2. They are defined by two conformations of the WPD loop and 4 conformations of the loop 110-120. Cluster 3 is a cluster of oxidized structures which have somewhat different conformation from cluster 2. Main difference between clusters 2 and 3 is conformation of Tyr46 and Arg47. The difference between clusters 5 and 6 is mainly in side-chains (it reaches up to $11.74 \AA$ for Met114). In this case Met114 and Glu115 are oriented in the opposite directions. Backbones look much the same in this case, but cluster 6 is twisted in the middle compared to 5, which leads to the opposite orientation of side-chains.

It follows from Table 2 that despite being quite flexible the loop 110-120 adopts the same conformation in most cases. Conformation of the loop 110-120 of the first cluster with 2CM8 as a centroid is the most typical one hereafter referred to as standard conformation. This is a conforma- tion of a $\beta$-strand type with two hydrogen bonds between Glu115 and Ser118 and a hydrogen bond between Val113(O) and Lys120. Besides that it is stabilized by additional internal and external hydrogen bonds. Internal hydrogen bonds are formed by Arg112. They include a bond between OE2 atom of Glu115 and N atom of Arg112 and another bond between ND atom of Asn111 and $\mathrm{O}$ atom of Arg112. The most interesting among external interactions is a salt bridge between Glu115 and Arg221 (Fig. 2).

In the case of open WPD loop (cluster 2) there are additional hydrogen bonds formed by Arg112. Guanidinium group of Arg112 interacts with Met114 (CO group) and a carboxylic group of Asp181. At this conformation, phenyl of Phe182 comes close to the side-chain of Lys116 (Fig. 1), though the distance is greater than needed for $\pi$-stacking. Both loops (WPD loop and the loop region comprised of residues 110-120) keep the entrance to the active site open.

An overview of the four conformations of the loop 110-120 is presented in Fig 3. Different non-standard conformations of the loop 110-120 are observed only when WPD loop is closed. Both

Table 2. Clusters of PDB structures

\begin{tabular}{c|c|c|c|c|c|c}
\hline Cluster & $\begin{array}{c}\text { Centroid } \\
\text { (PDB code) }\end{array}$ & $\begin{array}{c}\text { Number of } \\
\text { structures }\end{array}$ & $\begin{array}{c}\text { RMSD from } \\
\text { 2CM8 }(\AA)\end{array}$ & WPDloop & $\begin{array}{c}\text { Loop 110-120 } \\
\text { conformation }\end{array}$ & Comments \\
\hline 1 & 2CM8 & 66 & 0 & Closed & 1 & \\
2 & $1 \mathrm{PH} 0$ & 21 & 1.88 & Open & 1 & \\
3 & 3SME & 3 & 2.75 & Open & 1 & Oxidized \\
4 & 1Q6P-B & 5 & 2.31 & Closed & 2 & \\
5 & 1Q6N-A & 1 & 2.86 & Closed & 3 & \\
6 & 1Q6T-B & 2 & 2.99 & Closed & 4 & \\
\hline
\end{tabular}




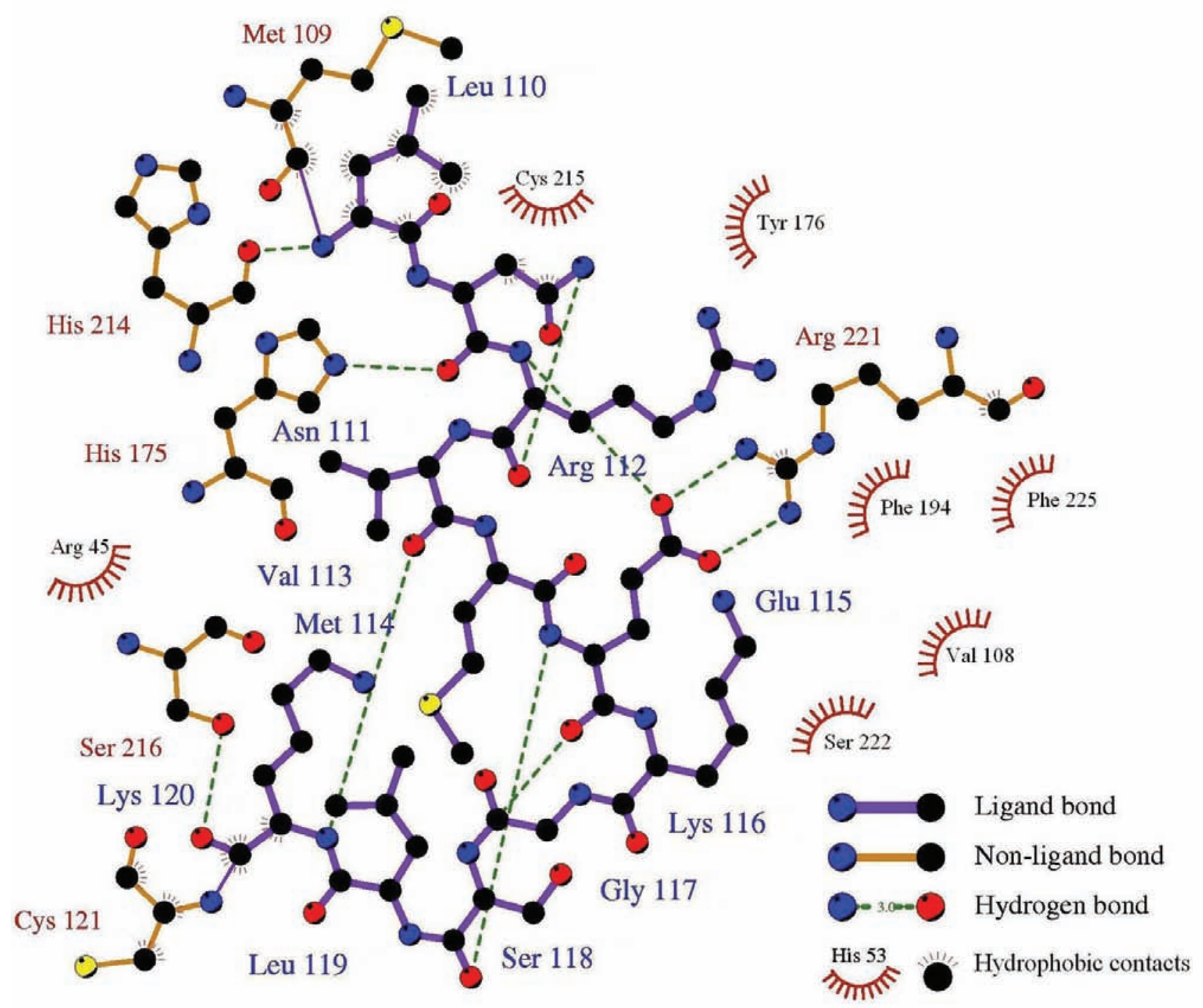

Fig. 2. Interaction between the loop 110-120 and amino acid residues of PTP1B (2CM8, cluster 1)

loops function near the catalytic center of the enzyme $[12,20]$ to take part in substrate recognition and binding. WPD loop is much more flexible and moves a distance of about $10 \AA$ between open and closed states. This supports the role of Asp181 acting as general acid/base in catalytic mechanism of substrate dephosphorylation. Many crystal structures of PTP1B have WPD loop closed onto an inhibitor [21]. In contrast, the X-ray crystal structures of PTP1B complexed with other ligands indicate that WPD loop can remain open [22]. At the same time, loop $110-120$ is more stable. It was suggested previously [15] that residues Val113Ser118 are important for WPD loop movement. However, the change between the initial and final state of R-loop, which shows the movement toward the active site, is relatively small (less than $1 \AA$ ).
According to our results of calculations of crystal structures, the loop 110-120 has a standard conformation which is changed only from time to time. It remains in the standard position when WPD loop is open. Nevertheless, the loop can change its conformation which happens at complexation with some kinds of bulky inhibitors. It is interesting to note that WPD loop in all such cases is closed. Three non-standard conformations are observed only for a limited number of structures. It is also evident from Table 3 that most non-standard conformations of the loop 110-120 are found in PDB files with multiple chains of PTP1B. It appeared that in five out of eight cases where several chains are present loop conformations are different from the most typical case 1. 1LQF contains four chains with the same standard conformation 1 . 


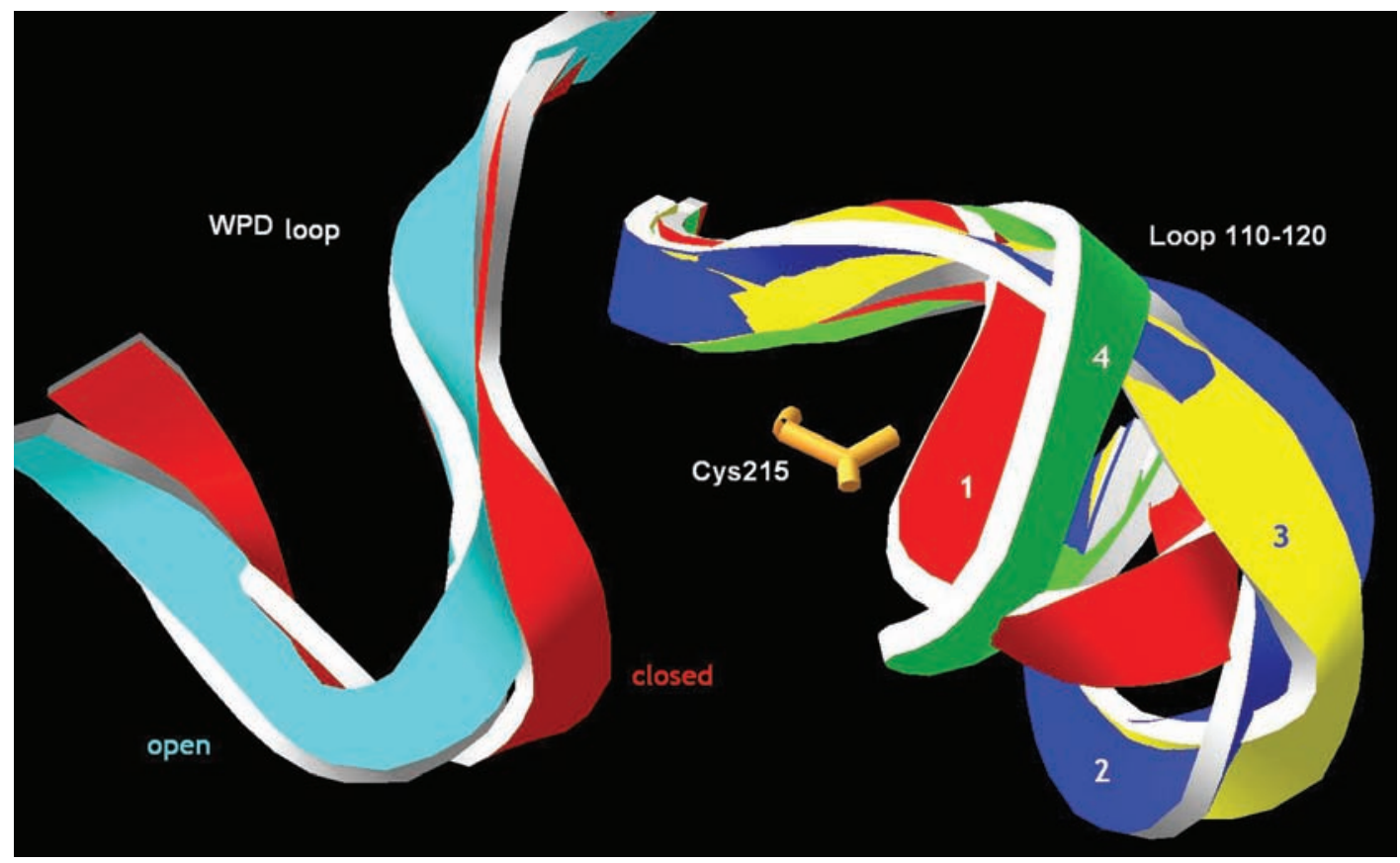

Fig. 3. Four conformations of the loop 110-120 (2CM8 - standard conformation 1), 1Q6P-B (conformation 2) $1 Q 6 N-A$ (conformation 3), 1Q6T-B (conformation 4); WPD loop is represented by open (1PHO) and closed (2CM8) conformations

Table 3. Conformations in PBD files with multiple chains

\begin{tabular}{c|cc}
\hline \multirow{2}{*}{ Name } & \multicolumn{2}{|c}{ Loop 110-120 conformation } \\
\cline { 2 - 3 } & Chain A & Chain B \\
\hline 1Q6N & 3 & 1 \\
1Q6P & 1 & 2 \\
1Q6S & 1 & 2 \\
1Q6T & 1 & 4 \\
2FJN & 4 & 2 \\
1JF7 & 1 & 1 \\
1LQF & 1 & 1 \\
2CM3 & 1 & 1 \\
\hline
\end{tabular}

${ }^{a} 1 \mathrm{LQF}$ contains 4 standard chains.

Besides that 1Q6J and 1Q6M, represented by only one chain, belong to type 2 .

Sometimes conformations of both chains are non-standard. Some of them differ markedly from the standard one (difference up to $11.4 \AA$ in the middle of the loop). This might be explained by the influences of bulky inhibitors, though they do interact only with the end of the loop 110-120 (residues 118-120). It is interesting to notice that in such cases active sites of the chains are located at a close distance (about $7 \AA$ for the closest residues) and can influence each other. The dimerization of PTP1B, which is anchored to the endoplasmic reticulum in vivo [23], and other different proteinprotein interactions may influence activity of PTP1B.

In conclusion, a special tool for comparison of selected parts of multiple PDB files for the same enzyme has been applied to investigate loop 110120 of PTP1B. It was found that the loop 110-120 of the PTP1B is not as mobile as it was expected. In most cases it adopts the same conformation. Most non-standard conformations are found in PDB files with multiple chains. The result may help in further understanding of PTP1B functioning and provide a starting points for the computer simulations of inhibitor binding. 


\section{АНАЛІЗ КОНФОРМАЦІЙНОЇ РУХЛИВОСТІ ПЕТЛІ 110-120 ПРОТЕЇНТИРОЗИНФОСФАТАЗИ 1В}

\author{
В. Ю. Танчук, В. О. Танін, А. І. Вовк
}

Інститут біоорганічної хімії та нафтохімії НАН України, Київ;

e-mail: v_tanchuk@yahoo.com; vovk@bpci.kiev.ua

Конформації каталітичного центру протеїнтирозинфосфатази 1В (РТР1В) та оточуючих петель відіграють важливу роль у каталізі й інгібуванні ензиму. 98 конформацій з 88 PDB файлів, які представлено РТР1В із різними лігандами, проаналізовано $з$ метою дослідження особливостей рухливості петлі

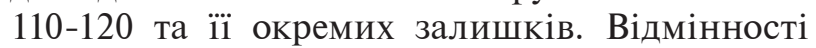
виявлено за допомогою спеціального програмного забезпечення, яке проводить багаторазове порівняння обраних частин $\mathrm{PDB}$ файлів. Конформації було розподілено на 6 кластерів. Виявлено, що петля, яка сформована залишками 110-120, може бути охарактеризована чотирма основними положеннями. Вона характеризується, переважно, основною конформацією і зберігає їі під час руху WPD петлі. Три інші конформації є стабільними у разі закритої WPD петлі та, ймовірно, $\epsilon$ вірогіднішими для РТР1В із субодиничною структурою.

Кл юч ов і слов а: протеїнтирозинфосфатаза 1В, центри зв'язування, конформації, кластеризація, структурна подібність, докінг.

\section{АНАЛИЗ КОНФОРМАЦИОННОЙ ПОДВИЖНОСТИ ПЕТЛИ 110-120 ПРОТЕИНТИРОЗИНФОСФАТАЗЫ 1В}

\section{В. Ю. Танчук, В. А. Танин, А. И. Вовк}

Институт биоорганической химии и нефтехимии НАН Украины, Киев; e-mail: v_tanchuk@yahoo.com; vovk@bpci.kiev.ua

Конформации каталитического центра протеинтирозинфосфатазы 1В (РТР1В) и окружающих петель играют важную роль при катализе и ингибировании энзима. 98 конформаций из 88 PDB файлов, представляющих РТР1В с разными лигандами, проанализированы с целью исследования особенностей подвижности петли 110-120 и ее отдельных остатков. Различия выявлены при помощи специального программного обеспечения, которое производит многократное сравнение выбранных частей PDB файлов. Конформации были распределены на 6 кластеров. Обнаружено, что петля, сформированная остатками 110-120, может быть охарактеризована четырьмя основными положениями. Она принимает, преимущественно, основную конформацию и сохраняет ее во время движения WPD петли. Три другие конформации являются стабильными в случае закрытой WPD петли и вероятно являются более выгодными для РТР1В с субъединичной структурой.

К л ючевы е с лова: протеинтирозинфосфатаза 1B, центры связывания, конформации, кластеризация, структурное подобие, докинг.

1. Alonso, A. Sasin J., Bottini N. et al. // Cell. 2004. - 117. - P. 699-711.

2. Tabernero L., Aricescu A. R., Jones E. Y. et al. // FEBS J. - 2008. - 275, N 5. - P. 867-882.

3. Kasibhatla B., Wos J., Peters K. G. // Curr. Opin. Invest. Drugs. - 2007. - 8, N 10. P. 805-813.

4. Koren S., Fantus I. G. // Best Pract. Res. Clin. Endocrinol. Metab. - 2007. - 21, N 4. P. 621-640.

5. Vintonyak V. V., Antonchick A. P., Rauh D. et al. // Curr. Opin. Chem. Biol. - 13, N 6. 2009. - P. 272-283.

6. Zhang S., Zhang Z. Y. // Drug Discov. Today 2007. - 12, N 9-10. - P. 373-381.

7. Zhang Z. Y. // Biochim. Biophys. Acta. 2005. - 1754, N 1-2. - P. 100-107.

8. Tautz L., Mustelin T. // Methods. - 2007. - 42, N 3. - P. 250-260.

9. Ни Х. // Bioorg. Med. Chem. Lett. - 2006. 16, N 24. - P. 6321-6327.

10. Saxena A. K., Pandey G., Gupta S. et al. // Bioorg. Med. Chem. Lett. - 2009. - 19, N 8. - P. 2320-2323.

11. Kurkcuoglu Z., Bakan A., Kocaman D. et al. // Comput. Biol. - 2012. - 8, N 9. - e1002705.

12. Wang J-F., Gong K., Wei D. et al. // Protein Eng. Des. Sel. - 2009. - 22, N 6. - P. 349-355.

13. Bernstein F., Koetzle T., Williams G. et al. // J. Mol. Biol. - 1977. - 112. - P. 535-542.

14. Tanchuk V. Y., Tanin V. O., Vovk A. I. // Chem. Biol. Drug Des. - 2012. - 80, N 1. - P. 121-128.

15. Kamerlin S. C. L., Rucker R., Boresch S. // Biochem. Biophys. Res. Commun. - 2006. 345, N 3. - P. 1161-1166.

16. Asante-Appiah E., Patel S., Desponts C. et al. // J. Biol Chem. - 2006. - 281, N 12. P. 8010-8015.

17. Scapin G., Patel S. B., Becker J. W. et al. // Biochemistry. - 2003. - 42, N 39. - P. 1145111459. 
18. Guex N., Peitsch M. C. // Electrophoresis. 1995. - 18. - P. 2714-2723.

19. Wallace A. C., Laskowski R. A., Thornton J. M. // Protein Eng. - 1995. - 8, N 2. - P. 127-134.

20. Peters G. H., Frimurer T. M., Andersen J. N. et al. // Biophys J. - 1999. - 77, N 1. - P. 505-515.

21. Sun J.-P., Fedorov A. A., Lee S.-Y. et al. // J. Biol. Chem. - 2003. - 278, N 14. - P. 1240612414.
22. Liu S., Zeng L.-F., Wu L. et al. // J. Am. Chem. Soc. - 2008. - 130, N 50. - P. 17075-17084.

23. Anderie I., Schulz I., Schmid A. // Exp Cell Res. - 2007. - 313, N 15. - P. 3189-3197.

Received 26.02.2013 